\title{
Response of Various Sesame Varieties under the Influence of Nitrogen and Phosphorus Doses
}

\author{
Shahab-u-Din Kashani1 ${ }^{*}$, Mahmoodah Buriro², Asif Nadeem³, Nazeer Ahmed1, \\ Zahid Saeed ${ }^{3}$, Fateh Mohammad', Shafeeque Ahmed' \\ ${ }^{1}$ Livestock Research Institute, Turbat, Pakistan \\ ${ }^{2}$ Sindh Agriculture University, Tandojam, Pakistan \\ ${ }^{3}$ Agriculture Extension, Panjgoor, Pakistan \\ Email: ${ }^{\text {Shahabkashani64@gmail.com }}$
}

Received 15 January 2015; accepted 14 February 2015; published 16 February 2015

Copyright (C) 2015 by authors and Scientific Research Publishing Inc.

This work is licensed under the Creative Commons Attribution International License (CC BY). http://creativecommons.org/licenses/by/4.0/

(c) () Open Access

\section{Abstract}

A field study to evaluate the "Response of various sesame (Sesamum indicum L.) varieties under the influence of nitrogen and phosphorus doses" was carried out at Oilseeds Section, Agriculture Research Institute, Tandojam during Kharif 2013. The experiment was laid out in a three repli-

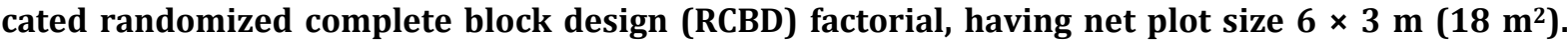
The treatments comprised two varieties such as S-17 and Pr-125, and six doses of NP i.e. (No fertilizer (Control), NP @ 30 - 30 kg.ha- ${ }^{-1}$, NP @ 50 - 30 kg.ha-1, NP @ 50 - 50 kg.ha-1, NP @ 70 - 50 kg.ha-1 and NP @ $70-70 \mathrm{~kg} \cdot \mathrm{ha}^{-1}$ ). The analysis of variance suggested that all the doses of NP affected significantly $(P<\mathbf{0 . 0 5})$ growth and yield of sesame varieties as compared to No fertilizer (Control) treatment. In the case of fertilizer doses, NP @ $70-70 \mathrm{~kg} \cdot \mathrm{ha}^{-1}$ produced maximum plant height $(102.33 \mathrm{~cm})$, branches plant ${ }^{-1}(18.50)$, capsules plant ${ }^{-1}(42.17)$, seeds capsule ${ }^{-1}(57.67)$, seed weight plant ${ }^{-1}(37.50 \mathrm{~g})$, seed index $(3.10 \mathrm{~g})$ and seed yield $\left(774.17 \mathrm{~kg} \cdot \mathrm{ha}{ }^{-1}\right)$, whereas NP @ $70+50 \mathrm{~kg} \cdot \mathrm{ha}^{-1}$ and NP @ $50-50 \mathrm{~kg} \cdot \mathrm{ha}^{-1}$ ranked 2nd and 3rd in all the growth and yield traits, particularly seed yield $\left(763.50 \mathrm{~kg} \cdot \mathrm{ha}^{-1}\right.$ and $\left.694.50 \mathrm{~kg} \cdot \mathrm{ha}^{-1}\right)$. Among sesame varieties, $S-17$ resulted in maximum plant height $(91.89 \mathrm{~cm})$, branches plant ${ }^{-1}(15.11)$, capsules plant ${ }^{-1}(37.06)$, seeds capsule $^{-1}(50.56)$, seed weight plant $^{-1}(32.00 \mathrm{~g})$, seed index $(2.63 \mathrm{~g})$ and seed yield (682.11 kg.ha- ${ }^{-1}$ ), whereas variety Pr-125 resulted in minimum traits, particularly seed yield (657.56 $\mathrm{kg} \cdot \mathrm{ha}^{-1}$ ). In the case of interactive effects, the interaction of NP @ $70-70 \mathrm{~kg} \cdot \mathrm{ha}^{-1} \times$ variety $\mathrm{S}-17^{-17}$ produced maximum values, particularly seed yield (782.67), whereas minimum results were recorded in the interaction of No fertilizer (Control) $\times$ variety Pr-125. Hence results concluded that the interaction of NP @ 70 - $50 \mathrm{~kg} \cdot \mathrm{ha}^{-1}$ variety S-17 was found most economical for obtaining optimum yield of sesame because of non-significant differences with NP @ 70 - 70 kg.ha-1.

*Corresponding author.

How to cite this paper: Kashani, S., Buriro, M., Nadeem, A., Ahmed, N., Saeed, Z., Mohammad, F. and Ahmed, S. (2015) Response of Various Sesame Varieties under the Influence of Nitrogen and Phosphorus Doses. American Journal of Plant Sciences, 6, 405-412. http://dx.doi.org/10.4236/ajps.2015.62046 
Keywords

Sesame, NP Doses, High Yield

\section{Introduction}

Sesame (Sesamum indicum L.) locally known as "til" is probably the most ancient oilseed known and used by man [1]. Sesame is known as the king of oil seeds due to the high oil content (50\% - 60\%) of its seed [2]. Sesame is one of the oldest cultivated plants in the world. It has early origins in East Africa and in India [3]. Sesame is a source of good quality edible and medicinal oil [4]. Til oil-cake is good feed for poultry, goat, sheep, fish, cattle, etc. Its seeds and young leaves are eaten as stews and soaps in Asia [5].

Pakistan is facing shortage of edible oil. The total availability of edible oil in 2008-09 was 2.821 million tons, while local production of edible oil was 684 thousand tons that is $24 \%$ of the total availability in the country. The remaining 76\% was made available through imports. During 2009-10, 1.246 million tons edible oil which amount to Rs. 77.78 billion has been imported, while the local production of edible oil was 0.680 million tons [6]. The are a under sesame cultivation in Sindh, Punjab, KPK and Balochistan during the year 2006 was 3.4, 75.1, 0.1 and 3.4 thousand hectares to accumulate total area in the country up to 82.0 thousand hectares with the production of 1.4, 31.6, 0.1 and 2.0 thousand tons, respectively [6]. The average yield unit ${ }^{-1}$ area of sesame obtained in Pakistan is also far below the potential yields due to a variety of factors. Nutrient deficiency is one of the important factors [7].

Nitrogen and phosphorus are essential nutrients required by the plants for their growth and vigour. Nitrogen is considered as an essential element of bio-molecules such as amino acids, proteins, nucleic acids, phytohormones and a number of enzymes and coenzymes. $\mathrm{N}$ strongly stimulates growth, expansion of the crop canopy and interception of solar radiation [8]. Similarly, phosphorus is an essential nutrient both as a part of several key plant structure compounds and as catalysis in the conversion of numerous key flower formation and seed production, more uniform and earlier crop maturity, improvements in crop quality, and increased resistance to plant diseases [9].

The nutrient applied is not readily available to the plants due to soil salinity; a sufficient quantity is leached or fixed in the soil. Balanced application of fertilizer like nitrogen and phosphorus play vital role in enhancing the yield of sesame, while indiscriminate use of these nutrients causes several problems like insect pests which causes considerable loss to the crop yield [10]. Saleem et al. (2012) found that significantly $(\mathrm{P}<0.05)$ more plant height, number of capsules plant ${ }^{-1}$, number of seeds plant ${ }^{-1}$, 1000-seeds weight and seed yield were recorded in sesame genotype TS-3. Among nitrogen levels, highest application rate $\left(90 \mathrm{~kg} \cdot \mathrm{ha}^{-1}\right)$ proved to be statistically best with respect to all growth, yield and quality attributes of sesame cultivars. The nitrogen use efficiency was recorded maximum at $60 \mathrm{~kg} \mathrm{~N} \mathrm{ha}^{-1}$ which was statistically at par with $90 \mathrm{~kg} \mathrm{~N} \mathrm{ha}^{-1}$ for both the varieties. The results also indicated that cultivar TS-3 gave more seed yield than strain 96,006 at the same rate of nitrogen application [7]. Olowe and Busari (2000) reported an increase in plant height of sesame at maturity from $104.6 \mathrm{~cm}$ with $0 \mathrm{~kg} \mathrm{~N}^{-1}$ to $122.9 \mathrm{~cm}$ with the application of $90 \mathrm{~kg} \mathrm{~N} \mathrm{ha}^{-1}$ [11]. In another study Malik et al. (2003) reported a significant increase in plant height of sesame from $127.48 \mathrm{~cm}$ with $0 \mathrm{~kg} \mathrm{~N} \mathrm{ha}^{-1}$ to 136.37 $\mathrm{cm}$ with the application of $80 \mathrm{~kg} \mathrm{~N}^{-1}$ [12]. $\mathrm{N}$ application has significant effects on some growth parameters of sesame with $90 \mathrm{~kg} \mathrm{~N} h a^{-1}$ producing maximum effect in plant height at flowering, number of leaves at eight weeks after sowing and number of secondary branches at harvest [13].

\section{Materials and Methods}

The experiment was laid out in a three replicated randomize complete block design (RCBD) factorial, having net plot size $6 \times 3 \mathrm{~m}\left(18 \mathrm{~m}^{2}\right)$. The treatments comprised two varieties (S-17 and Pr-125) and six doses of NP i.e. (No fertilizer (Control), NP@30 - 30 kg ha ${ }^{-1}$, NP @ 50 - $30 \mathrm{~kg} \cdot \mathrm{ha}^{-1}$, NP @ 50 - $50 \mathrm{~kg} \cdot \mathrm{ha}{ }^{-1}$, NP @ 70 - $50 \mathrm{~kg} \cdot \mathrm{ha}{ }^{-1}$ and NP@ $70-70 \mathrm{~kg} \cdot h a^{-1}$ ). For preparation of seedbed disc harrow was run to open and pulverize the soil, and later the land was leveled and planked. After soaking dose, when the land came in condition, the cultivator was used, followed by rotavator. A total of 36 plots were prepared and the treatments were managed in such a way to separate the treatments and replications easily, while the channels and bunds were developed to facilitate the ir- 
rigation water application and interculturing. The seed of sesame varieties was sown with the help of single row hand drill. The row to row spacing of $45 \mathrm{~cm}$ and plant to plant distance $15 \mathrm{~cm}$ was maintained. Fertilizers NP were applied as per treatments. Full dose of $\mathrm{P}$ in the form of DAP, whereas half dose of $\mathrm{N}$ in the form of Urea were applied at the time of sowing. Remaining half dose of Nitrogen was applied at the time of first irrigation. First irrigation at 21 DAS as recommended, whereas subsequent irrigations keeping in view soil moisture condition and crop requirement were applied. In all three irrigations were applied. The weeds were controlled by interculturing at 1st and 2nd irrigations. These observations were recorded plant height $(\mathrm{cm})$, branches plant ${ }^{-1}$, capsules plant $^{-1}$, seeds capsule ${ }^{-1}$, seed weight plant ${ }^{-1}(\mathrm{~g})$, seed index (1000 seed weight, g), seed yield $\left(\mathrm{kg} \cdot \mathrm{ha}^{-1}\right)$.

\section{Result and Discussions}

Nutrient deficiency and imbalanced fertilizers use are one of the important factors for low yield of sesame in Pakistan. Nitrogen is essential element of bio-molecules such as amino acids, proteins, nucleic acids and enzymes. It stimulates growth, expansion of the crop canopy and interception of solar radiation [8]. Phosphorus is an essential nutrient both as a part of several key plant structure compounds and stimulates root development, increase stem strength, improve flower formation and seed production, more uniform and earlier crop maturity.

The results of present study Table 1 showed that different levels of nitrogen and phosphorus significantly ( $\mathrm{P}$ $<0.05$ ) affected almost all the growth and yield attributes of sesame varieties, particularly seed yield. In case of fertilizer, maximum plant height $(\mathrm{cm})$, branches plant ${ }^{-1}$, capsules plant ${ }^{-1}$, seeds capsule ${ }^{-1}$, seed weight plant ${ }^{-1}(\mathrm{~g})$, seed index (1000 seed weight, g) and seed yield $\left(774.17 \mathrm{~kg} \cdot \mathrm{ha}^{-1}\right)$ were recorded in NP @ 70 - $70 \mathrm{~kg} \cdot \mathrm{ha}^{-1}$, followed by NP@ 70 - $50 \mathrm{~kg} \cdot \mathrm{ha}^{-1}$, whereas minimum growth and yield parameters were noted in No fertilizer (Control) [10]. Among, varieties maximum growth and yield parameters, particularly seed yield (682.11 kg.ha ${ }^{-1}$ ) were obtained in S-17, whereas minimum growth and yield traits were recorded in variety Pr-125. As regards interactive effects, maximum growth and yield parameters, particularly seed yield $\left(782.67 \mathrm{~kg} \cdot \mathrm{ha}^{-1}\right)$ were obtained in the interaction of NP @ 70 - $50 \mathrm{~kg} \cdot \mathrm{ha}^{-1}$ variety S-17, whereas minimum growth and yield trait were recorded in the interaction of No fertilizer (Control) variety Pr-125. In this study, although numerically the data of different parameters recorded for NP @ 70 - $50 \mathrm{~kg} \cdot \mathrm{ha}^{-1}$ was higher but statistical analysis showed that the results between NP@70 - 70 kg.ha ${ }^{-1}$ and NP@ 70 - $50 \mathrm{~kg} \cdot \mathrm{ha}^{-1}$ were non-significant with each other for almost all the parameters, particularly seed yield. The superiority of NP @ $70-50 \mathrm{~kg} \cdot \mathrm{ha}^{-1}$ for studied parameters of sesame varieties could possibly be because of optimum availability and uptake of nutrients [14]. The results of our study conform the results of Shakar et al. (2000) who suggested that sesame genotype TS-3 gave significantly higher seed yield than the other genotypes due to higher number of capsules plant ${ }^{-1}$, number of seeds capsule $^{-1}$ and 1000 -seed weight. TS-3 also proved better in oil contents. Yield and yield components were also influenced significantly by NP application [15]. Maximum increase of $13 \%$ in seed yield was recorded at NP level of $50-50 \mathrm{~kg} \cdot \mathrm{ha}^{-1}$. The increase in seed yield with NP application was mainly due to higher number of capsules plant $^{-1}$, number of seeds capsule ${ }^{-1}$ and 1000-seed weight. Oil contents were also influenced significantly by NP application being maximum (48\%) at NP level of $50-50 \mathrm{~kg} \cdot \mathrm{ha}^{-1}$. The results are also in agreement with the findings of Umar et al. (2012) who revealed that interaction of nitrogen level and intra row spacing produced highest values for number of leaves, number of primary branches, shoot dry matter, capsule yield and seed yield plant $^{-1}$ at $80 \mathrm{~kg} \mathrm{~N} \mathrm{ha}^{-1}$ and $15 \mathrm{~cm}$ intra row spacing of sesame [16]. Similar findings were also reported by Saleem et al. (2012) who suggested that highest application rate $\left(90 \mathrm{~kg} \cdot \mathrm{ha}^{-1}\right)$ proved to be statistically best with respect to all growth, yield and quality attributes of sesame cultivars [7]. The nitrogen use efficiency (agronomic and physiological efficiency) was recorded maximum at $60 \mathrm{~kg} \mathrm{~N}^{-1}$ which was statistically at par with $90 \mathrm{~kg} \mathrm{~N} \mathrm{ha}^{-1}$ for both the varieties. The results also indicated that cultivar TS-3 gave more seed yield than strain 96,006 at the same rate of nitrogen application. In another study, Shehu et al. (2010) reported that highest number of branches, leaves, seeds pod ${ }^{-1}$, seed yield and dry matter was recorded from the highest $\mathrm{N}$ rate of $112.5 \mathrm{~kg} \cdot \mathrm{ha}^{-1}$. Optimum number of leaves and dry matter was attained at $112.5 \mathrm{~kg} \mathrm{~N} \mathrm{ha}^{-1}$ while number of pods and seed yield were attained at $75 \mathrm{~kg} \mathrm{~N} \mathrm{ha}^{-1}$. Number of seeds pod $^{-1}$ was not significantly affected by $\mathrm{N}$ application [17].

The results about plant height $(\mathrm{cm})$ of sesame varieties as affected by different doses of nitrogen and phosphorus are presented in Table 2 and their analysis of variance exhibited significant $(\mathrm{P}<0.05)$ effect of nitrogen and phosphorus doses and varieties, whereas non-significant $(\mathrm{P}>0.05)$ effect for their interaction on plant height (cm) [16]. 
Table 1. Growth and yield parameter of sesame as influence by NP doses.

\begin{tabular}{|c|c|c|c|c|c|c|c|}
\hline Varieties & $\begin{array}{l}\text { Plant height } \\
\text { (cm) }\end{array}$ & $\begin{array}{c}\text { Branches } \\
\text { plant }^{-1}\end{array}$ & $\begin{array}{c}\text { Capsule } \\
\text { plant }^{-1}\end{array}$ & Seeds capsule $^{-1}$ & $\begin{array}{l}\text { Seed weight } \\
\text { plant }^{-1}\end{array}$ & $\begin{array}{l}\text { Seed index (1000 } \\
\text { seed weight, g) }\end{array}$ & $\begin{array}{c}\text { Seed yield } \\
\left(\mathbf{k g}^{\prime} \cdot \mathbf{h a}^{-1}\right)\end{array}$ \\
\hline S-17 & 91.89 a & 15.11 a & $37.06 \mathrm{a}$ & 50.56 a & $32.00 \mathrm{a}$ & $2.63 \mathrm{a}$ & $682.11 \mathrm{a}$ \\
\hline Pr-125 & $88.56 \mathrm{~b}$ & $13.06 \mathrm{~b}$ & $34.11 \mathrm{~b}$ & $47.17 \mathrm{~b}$ & $29.06 \mathrm{~b}$ & $2.47 \mathrm{~b}$ & $657.56 \mathrm{~b}$ \\
\hline LSD $0.05 \%$ & 3.0071 & 1.8914 & 2.1383 & 2.5111 & 2.5975 & 0.1627 & 15.845 \\
\hline LSD $0.01 \%$ & -- & -- & 2.9064 & 3.4130 & -- & -- & 21.537 \\
\hline \multicolumn{8}{|l|}{$\begin{array}{l}\text { NP doses } \\
\left(\text { kg }^{-1} \mathbf{h a}^{-1}\right)\end{array}$} \\
\hline Control & 55.50 e & $5.83 \mathrm{~d}$ & $18.50 \mathrm{c}$ & $25.50 \mathrm{~d}$ & $13.00 \mathrm{~d}$ & $1.65 \mathrm{~d}$ & $485.00 \mathrm{~d}$ \\
\hline NP@ @ 30 - 30 & $90.33 \mathrm{~d}$ & 11.67 c & $35.00 \mathrm{~b}$ & $49.00 \mathrm{c}$ & 30.17 c & $2.25 \mathrm{c}$ & 630.17 c \\
\hline NP@ @ 50 - 30 & $95.00 \mathrm{~cd}$ & $15.00 \mathrm{~b}$ & $37.50 \mathrm{~b}$ & 51.50 c & $32.50 \mathrm{bc}$ & $2.60 \mathrm{~b}$ & $671.67 \mathrm{~b}$ \\
\hline NP@ 50 - 50 & 97.00 bc & $15.83 \mathrm{ab}$ & $38.67 \mathrm{ab}$ & 53.00 bc & 33.50 abc & $2.70 \mathrm{~b}$ & $694.50 \mathrm{~b}$ \\
\hline NP@70-50 & $101.17 \mathrm{ab}$ & $17.67 \mathrm{ab}$ & 41.67 a & $56.50 \mathrm{ab}$ & $36.50 \mathrm{ab}$ & $3.00 \mathrm{a}$ & $763.50 \mathrm{a}$ \\
\hline NP@ @70 - 70 & $102.33 \mathrm{a}$ & 18.50 a & 42.17 a & 57.67 a & $37.50 \mathrm{a}$ & $3.10 \mathrm{a}$ & 774.17 a \\
\hline LSD $0.05 \%$ & 5.2084 & 3.2201 & 3.7037 & 4.3483 & 4.4996 & 0.2818 & 27.445 \\
\hline LSD $0.01 \%$ & 7.0791 & 4.3774 & 5.0340 & 5.9114 & 6.1156 & 0.3830 & 37.303 \\
\hline $\begin{array}{l}\text { Interaction } \\
(\mathrm{V} \times \mathrm{F})\end{array}$ & NS & NS & NS & NS & NS & NS & NS \\
\hline
\end{tabular}

Table 2. Plant height $(\mathrm{cm})$ of sesame varieties under the impact of nitrogen and phosphorus doses.

\begin{tabular}{|c|c|c|c|}
\hline \multirow{2}{*}{ NP doses $\left(\mathbf{k g} \cdot \mathrm{ha}^{-1}\right)$} & \multicolumn{2}{|c|}{ Varieties } & \multirow{2}{*}{ Mean } \\
\hline & S-17 & Pr-125 & \\
\hline No fertilizer (Control) & 59.33 & 51.67 & $55.50 \mathrm{e}$ \\
\hline NP @ 30 - 30 & 91.33 & 89.33 & $90.33 \mathrm{~d}$ \\
\hline NP@ @ 50 - 30 & 96.00 & 94.00 & $95.00 \mathrm{~cd}$ \\
\hline NP@ 50 - 50 & 99.00 & 95.00 & $97.00 \mathrm{bc}$ \\
\hline NP@ @ 70 - 50 & 102.00 & 100.33 & 101.17 ab \\
\hline NP@ @70 - 70 & 103.67 & 101.00 & 102.33 a \\
\hline Mean & 91.89 a & $88.56 \mathrm{~b}$ & - \\
\hline
\end{tabular}

Means not sharing the same letter in a column differ significantly at 0.05 probability level.

\begin{tabular}{cccc}
\hline & Varieties (V) & NP doses (F) & V $\times \mathbf{F}$ \\
SE \pm & 1.4500 & 2.5114 & 3.5517 \\
LSD 0.05 & 3.0071 & 5.2084 & -- \\
LSD 0.01 & -- & 7.0791 \\
\hline
\end{tabular}

The data regarding branches plant ${ }^{-1}$ of sesame varieties as affected by different doses of nitrogen and phosphorus are presented in Table 3 and their analysis of variance exhibited significant $(P<0.05)$ effect of NP doses and varieties, whereas non-significant $(\mathrm{P}>0.05)$ effect for their interaction on branches plant ${ }^{-1}[16]$. 
The results in relation to capsules plant ${ }^{-1}$ of sesame varieties as affected by different doses of nitrogen and phosphorus are presented in Table 4 and their analysis of variance exhibited significant $(\mathrm{P}<0.05)$ effect of nitrogen and phosphorus doses and varieties, whereas non-significant $(\mathrm{P}>0.05)$ effect for their interaction on capsules plant ${ }^{-1}[16]$.

The data regarding seeds plant ${ }^{-1}$ of sesame varieties as affected by different doses of nitrogen and phosphorus are presented in Table 5 and their analysis of variance exhibited significant $(\mathrm{P}<0.05)$ effect of nitrogen and

Table 3. Branches plant ${ }^{-1}$ of sesame varieties under the impact of nitrogen and phosphorus doses.

\begin{tabular}{|c|c|c|c|}
\hline \multirow{2}{*}{ NP doses $\left(\mathrm{kg} \cdot \mathrm{ha}^{-1}\right)$} & \multicolumn{2}{|c|}{ Varieties } & \multirow{2}{*}{ Mean } \\
\hline & S-17 & Pr-125 & \\
\hline No fertilizer (Control) & 6.67 & 5.00 & $5.83 \mathrm{~d}$ \\
\hline NP@ @ 30 - 30 & 12.33 & 11.00 & $11.67 \mathrm{c}$ \\
\hline NP@ 90 - 30 & 16.00 & 14.00 & $15.00 \mathrm{~b}$ \\
\hline NP@ 50 - 50 & 16.67 & 15.00 & $15.83 \mathrm{ab}$ \\
\hline NP@ @ 70 - 50 & 19.00 & 16.33 & $17.67 \mathrm{ab}$ \\
\hline NP@ @70 - 70 & 20.00 & 17.00 & $18.50 \mathrm{a}$ \\
\hline Mean & 15.11 a & $13.06 \mathrm{~b}$ & - \\
\hline
\end{tabular}

Means not sharing the same letter in a column differ significantly at 0.05 probability level.

\begin{tabular}{cccc} 
& Varieties (V) & NP doses (F) & V $\times \mathbf{F}$ \\
SE \pm & 0.8966 & 1.5529 & 2.1962 \\
LSD 0.05 & 1.8594 & 3.2206 & -- \\
LSD 0.01 & -- & 4.3774 \\
\hline
\end{tabular}

Table 4. Capsules plant ${ }^{-1}$ of sesame varieties under the impact of nitrogen and phosphorus doses.

\begin{tabular}{|c|c|c|c|}
\hline \multirow{2}{*}{ NP doses $\left(\mathbf{k g} \cdot \mathrm{ha}^{-1}\right)$} & \multicolumn{2}{|c|}{ Varieties } & \multirow{2}{*}{ Mean } \\
\hline & S-17 & Pr-125 & \\
\hline No fertilizer (Control) & 20.00 & 17.00 & $18.50 \mathrm{c}$ \\
\hline NP@ 30 - 30 & 36.00 & 34.00 & $35.00 \mathrm{~b}$ \\
\hline NP@ 90 - 30 & 39.00 & 36.00 & $37.50 \mathrm{~b}$ \\
\hline NP@ 90 - 50 & 40.33 & 37.00 & $38.67 \mathrm{ab}$ \\
\hline NP@ @70 - 50 & 43.00 & 40.33 & 41.67 a \\
\hline NP@ @ 70 - 70 & 44.00 & 40.33 & 42.17 a \\
\hline Mean & $37.06 \mathrm{a}$ & $34.11 \mathrm{~b}$ & - \\
\hline
\end{tabular}

Means not sharing the same letter in a column differ significantly at 0.05 probability level.

\begin{tabular}{cccc}
\hline & Varieties (V) & NP doses (F) & $\mathbf{V} \times \mathbf{F}$ \\
SE \pm & 1.0311 & 1.7859 & 2.5256 \\
LSD 0.05 & 2.1383 & 3.7037 & -- \\
LSD 0.01 & 2.9064 & 5.0340 & -- \\
\hline
\end{tabular}


phosphorus doses and varieties, whereas non-significant $(\mathrm{P}>0.05)$ effect for their interaction on seeds plant ${ }^{-1}$ [16].

The data about seed weight plant ${ }^{-1}(\mathrm{~g})$ of sesame varieties as affected by different doses of nitrogen and phosphorus are presented in Table 6 and their analysis of variance exhibited significant $(\mathrm{P}<0.05)$ effect of nitrogen and phosphorus doses and varieties, whereas non-significant $(\mathrm{P}>0.05)$ effect for their interaction on seed weight plant $^{-1}$ (g) [16].

Table 5. Seeds capsule ${ }^{-1}$ of sesame varieties under the impact of nitrogen and phosphorus doses.

\begin{tabular}{|c|c|c|c|}
\hline \multirow{2}{*}{ NP doses $\left(\mathrm{kg} \cdot \mathrm{ha}^{-1}\right)$} & \multicolumn{2}{|c|}{ Varieties } & \multirow{2}{*}{ Mean } \\
\hline & S-17 & Pr-125 & \\
\hline No fertilizer (Control) & 28.00 & 23.00 & $25.50 \mathrm{~d}$ \\
\hline NP@ @ 30 - 30 & 50.00 & 48.00 & $49.00 \mathrm{c}$ \\
\hline NP@ 90 - 30 & 53.00 & 50.00 & $51.50 \mathrm{c}$ \\
\hline NP@ @ 50 - 50 & 55.00 & 51.00 & 53.00 bc \\
\hline NP@ @ 70 - 50 & 58.00 & 55.00 & $56.50 \mathrm{ab}$ \\
\hline NP@70 - 70 & 59.33 & 56.00 & $57.67 \mathrm{a}$ \\
\hline Mean & 50.56 a & $47.17 \mathrm{~b}$ & - \\
\hline
\end{tabular}

Means not sharing the same letter in a column differ significantly at 0.05 probability level.

\begin{tabular}{cccc}
\hline & Varieties (V) & NP doses (F) & V $\times \mathbf{F}$ \\
\hline SE \pm & 1.2108 & 2.0972 & 2.9659 \\
LSD 0.05 & 2.5111 & 4.3493 & -- \\
LSD 0.01 & 3.4130 & 5.9114 & -- \\
\hline
\end{tabular}

Table 6. Seed weight plant ${ }^{-1}$ (g) of sesame varieties under the impact of nitrogen and phosphorus doses.

\begin{tabular}{|c|c|c|c|}
\hline \multirow{2}{*}{ NP doses $\left(\mathrm{kg} \cdot \mathrm{ha}^{-1}\right)$} & \multicolumn{2}{|c|}{ Varieties } & \multirow{2}{*}{ Mean } \\
\hline & S-17 & Pr-125 & \\
\hline No fertilizer (Control) & 15.00 & 11.00 & $13.00 \mathrm{~d}$ \\
\hline NP @ 30 - 30 & 31.00 & 29.33 & $30.17 \mathrm{c}$ \\
\hline NP@ 50 - 30 & 34.00 & 31.00 & $32.50 \mathrm{bc}$ \\
\hline NP@ 50 - 50 & 35.00 & 32.00 & 33.50 abc \\
\hline NP@ 90 - 50 & 38.00 & 35.00 & $36.50 \mathrm{ab}$ \\
\hline NP@ 90 - 70 & 39.00 & 36.00 & $37.50 \mathrm{a}$ \\
\hline Mean & $32.00 \mathrm{a}$ & $29.06 \mathrm{~b}$ & - \\
\hline
\end{tabular}

Means not sharing the same letter in a column differ significantly at 0.05 probability level.

\begin{tabular}{cccc}
\hline & Varieties (V) & NP doses (F) & V $\times \mathbf{F}$ \\
\hline SE \pm & 1.2525 & 2.1694 & 3.0680 \\
LSD 0.05 & 2.5975 & 4.4990 & -- \\
LSD 0.01 & -- & 6.1150 & -- \\
\hline
\end{tabular}


The results regarding seed index (1000 seed weight, g) of sesame varieties as affected by different doses of nitrogen and phosphorus are presented in Table 7 and their analysis of variance exhibited significant $(\mathrm{P}<0.05)$ effect of nitrogen and phosphorus doses and varieties, whereas non-significant $(P>0.05)$ effect for their interaction on seed index (g) [16].

The results regarding seed yield $\left(\mathrm{kg} \cdot \mathrm{ha}^{-1}\right)$ of sesame varieties as affected by different doses of nitrogen and phosphorus are presented in Table 8 and their analysis of variance exhibited significant $(\mathrm{P}<0.05)$ effect of nitrogen and phosphorus doses and varieties, whereas non-significant $(\mathrm{P}>0.05)$ effect for their interaction on seed yield $\left(\mathrm{kg} \cdot \mathrm{ha}^{-1}\right)$ [16].

Table 7. Seed index (1000 seed weight, g) of sesame varieties under the impact of nitrogen and phosphorus doses.

\begin{tabular}{|c|c|c|c|}
\hline \multirow{2}{*}{ NP doses $\left(\mathrm{kg} \cdot \mathrm{ha}^{-1}\right)$} & \multicolumn{2}{|c|}{ Varieties } & \multirow{2}{*}{ Mean } \\
\hline & S-17 & Pr-125 & \\
\hline No fertilizer (Control) & 1.70 & 1.60 & $1.65 \mathrm{~d}$ \\
\hline NP@ @ 30 - 30 & 2.30 & 2.20 & $2.25 \mathrm{c}$ \\
\hline NP@ 90 - 30 & 2.70 & 2.50 & $2.60 \mathrm{~b}$ \\
\hline NP@50-50 & 2.80 & 2.60 & $2.70 \mathrm{~b}$ \\
\hline NP@ @70 - 50 & 3.10 & 2.90 & $3.00 \mathrm{a}$ \\
\hline NP@70 - 70 & 3.20 & 3.00 & $3.10 \mathrm{a}$ \\
\hline Mean & $2.63 \mathrm{a}$ & $2.47 \mathrm{~b}$ & - \\
\hline
\end{tabular}

Means not sharing the same letter in a column differ significantly at 0.05 probability level.

\begin{tabular}{cccc}
\hline & Varieties $(\mathbf{V})$ & NP doses $(\mathbf{F})$ & $\mathbf{V} \times \mathbf{F}$ \\
\hline SE \pm & 0.0784 & 0.1359 & 0.1921 \\
LSD 0.05 & 0.1627 & 0.2818 & - \\
LSD 0.01 & -- & 0.3830 & -- \\
\hline
\end{tabular}

Table 8. Seed yield $\left(\mathrm{kg} \cdot \mathrm{ha}^{-1}\right)$ of sesame varieties under the impact of nitrogen and phosphorus doses.

\begin{tabular}{|c|c|c|c|}
\hline \multirow{2}{*}{ NP doses $\left(\mathbf{k g} \cdot \mathrm{ha}^{-1}\right)$} & \multicolumn{2}{|c|}{ Varieties } & \multirow{2}{*}{ Mean } \\
\hline & S-17 & Pr-125 & \\
\hline No fertilizer (Control) & 493.33 & 476.67 & $485.00 \mathrm{~d}$ \\
\hline NP @ 30 - 30 & 635.00 & 625.33 & $630.17 \mathrm{c}$ \\
\hline NP@ 90 - 30 & 696.67 & 646.67 & $671.67 \mathrm{~b}$ \\
\hline NP@ 90 - 50 & 713.33 & 675.67 & $694.50 \mathrm{~b}$ \\
\hline NP@ @ 70 - 50 & 771.67 & 755.33 & 763.50 a \\
\hline NP@ @ 70 - 70 & 782.67 & 765.67 & 774.17 a \\
\hline Mean & 682.11 a & $657.56 \mathrm{~b}$ & - \\
\hline
\end{tabular}

Means not sharing the same letter in a column differ significantly at 0.05 probability level.

\begin{tabular}{cccc}
\hline & Varieties $(\mathbf{V})$ & NP doses $(\mathbf{F})$ & $\mathbf{V} \times \mathbf{F}$ \\
\hline SE \pm & 7.6405 & 13.234 & 18.715 \\
LSD 0.05 & 15.845 & 27.445 & - \\
LSD 0.01 & 21.537 & 37.303 & -- \\
\hline
\end{tabular}




\section{Conclusion}

The results concluded that growth and yield traits particularly seed yield of sesame varieties were significantly $(\mathrm{P}<0.05)$ affected by all the doses of nitrogen and phosphorus. Application of NP @ 70 - $70 \mathrm{~kg} \cdot \mathrm{ha}^{-1}$ produced maximum values for all the attributes, particularly seed yield $\left(774.17 \mathrm{~kg} \cdot \mathrm{ha}^{-1}\right)$ showing non-significant statistical differences with NP @ $70-50 \mathrm{~kg} \cdot \mathrm{ha}^{-1}$. In the case of varieties, maximum parameters, particularly seed yield $\left(682.11 \mathrm{~kg} \cdot \mathrm{ha}^{-1}\right)$ were recorded in S-17. Among interactive effects, the interaction of NP @ 70 - $70 \mathrm{~kg} \cdot \mathrm{ha}^{-1} \mathrm{vari}-$ ety S-17 produced maximum seed yield $\left(782.67 \mathrm{~kg} \cdot \mathrm{ha}^{-1}\right)$.

\section{Acknowledgements}

The author (S K) is highly grateful to Dr. Mahmoodah Buriro, Department of Agronomy, Sindh Agriculture University, Tando jam, for their technical and support throughout the research Project.

\section{References}

[1] Wikipedia (2007) Sesame: From Wikipedia, the Free Encyclopedia Wikimedia Foundation, Inc. Last Modified on 12th September, 2007.

[2] Toan, D.P., Thuy-Duong, T.N.A., Carlsson, S. and Bui, T.M. (2010) Morphological Evaluation of Sesame (Sesamum indicum L.) Varieties from Different Origins. Australian Journal of Crop Science, 4, 498-504.

[3] Bedigian, D. (2003) Evolution of Sesame Revisited: Domestication, Diversity and Prospects. Genetic Resources and Crop Evolution, 50, 779-787. http://dx.doi.org/10.1023/A:1025029903549

[4] Khan, M.H.A., Sultana, N.A., Islam, M.N. and Hasan-uz-zaman, M. (2009) Yield and Yield Contributing Characters of Sesame as Affected by Different Management Practices. American-Eurasian Journal of Scientific Research, 4, 195197.

[5] Pakissan.com (2010) Sesame Production Practices in Pakistan. http://www.pakissan.com/english/allabout/crops/sesame

[6] G.O.P. (2010) Economic Survey of Pakistan 2009-2010. Ministry of Food, Agriculture and Livestock, Finance Division, Economic Advisor Wing, Islamabad, 36.

[7] Saleem, M.F., Ma, B.L., Malik, M.A., Cheema, M.A. and Wahid, M.A. (2008) Yield and Quality Response of Sesame (Sesamum indicum L.) to Irrigation Frequencies and Planting Patterns. Canadian Journal of Plant Science, 88, 101-109. http://dx.doi.org/10.4141/CJPS07052

[8] Eckert, D. (2010) Efficient Fertilizer Use-Nitrogen. 1-19.

[9] Bill, G. (2010) Efficient Fertilizer Use-Phosphorus. 1-7.

[10] Haruna, I.M., Aliyu, L., Olufajo, O.O. and Odion, E.C. (2011) Growth of Sesame (Sesamum indicum L.) as Influenced by Poultry Manure, Nitrogen and Phosphorus in Samaru, Nigeria. American-Eurasian Journal of Scientific Research, 10, 561-568.

[11] Olowe, V.I.O. and Busari, L.D. (2000) Response of Sesame (Sesamum indicum L.) to Nitrogen and Phosphorous Application in Southern Guinea Savanna of Nigeria. Tropical Oilseeds Journal, 5, 30-37.

[12] Malik, A.M., Saleem, M.F., Cheema, M.A. and Ahmed, S. (2003) Influence of Different Nitrogen Levels on Productivity of Sesame (Sesamum indicum L.) under Varying Planting Patterns. International Journal of Agriculture and Biology, 4, 490-492.

[13] Muhamman, M.A. and Gungula, D.T. (2008) Growth Parameters of Sesame (Sesamum indicum L.) as Affected by Nitrogen and Phosphorous Levels in Mubi, Nigeria. Journal of Sustainable Development in Agriculture \& Environment, 3, 80-86.

[14] Iftikhar Hussain Bhatti, R.A. and Nazir, M.S. (2005) Agronomic Traits of Sesame as Affected by Grain Legumes Intercropping and Plating Patterns. Pakistan Journal of Agricultural Sciences, 42, 56-60.

[15] Sharar, M.S., Ayub, M., Choudhry, M.A. and Asif, M. (2000) Growth and Yield of Sesame Genotypes as Influenced by NP Application. International Journal of Agriculture \& Biology, 2, 86-88.

[16] Umar, U.A., Mahmud, M., Abubakar, I.U., Babaji, B.A. and Idris, U.D. (2012) Effect of Nitrogen Fertilizer Level and Intrarow Spacing on Growth and Yield of Sesam (Sesamum indicun L.) Varieties. International Journal of Agronomy and Plant Production, 3, 139-144.

[17] Shehu, H.E., Kwari, J.D. and Sandabe, M.K. (2010) Nitrogen, Phosphorus and Potassium Nutrition of Sesame (Sesamum indicum) in Mubi, Nigeria. New York Science Journal, 3, 21-27. 
Scientific Research Publishing (SCIRP) is one of the largest Open Access journal publishers. It is currently publishing more than 200 open access, online, peer-reviewed journals covering a wide range of academic disciplines. SCIRP serves the worldwide academic communities and contributes to the progress and application of science with its publication.

Other selected journals from SCIRP are listed as below. Submit your manuscript to us via either submit@scirp.org or Online Submission Portal.
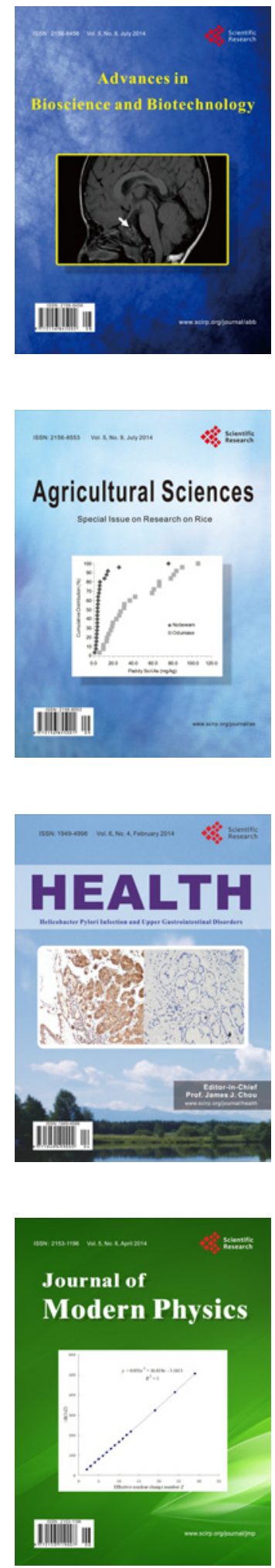
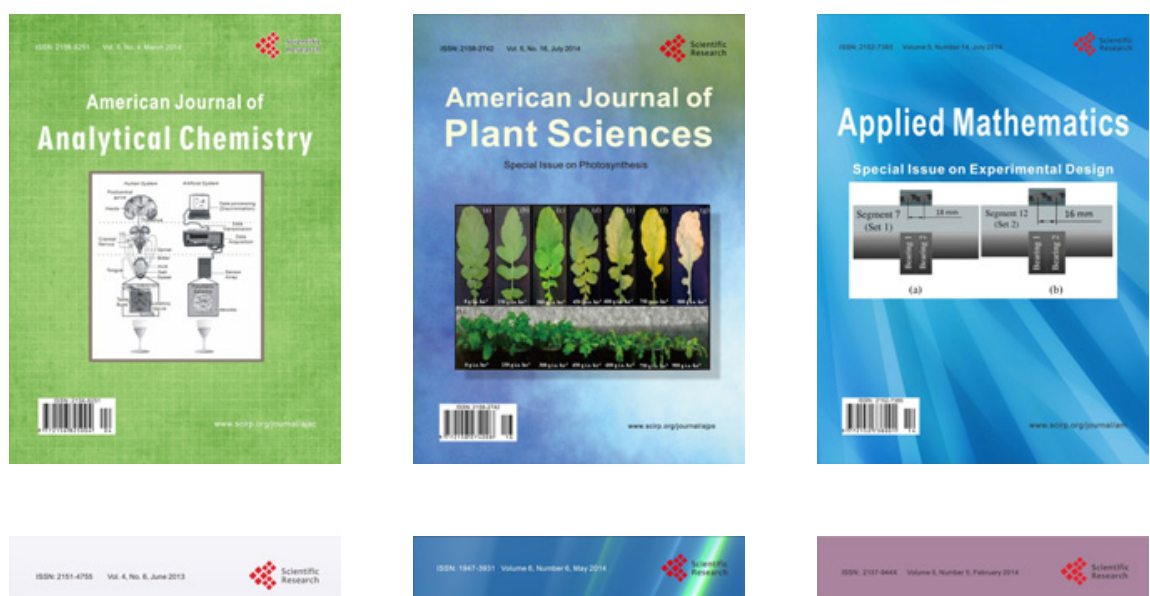

Creative Education
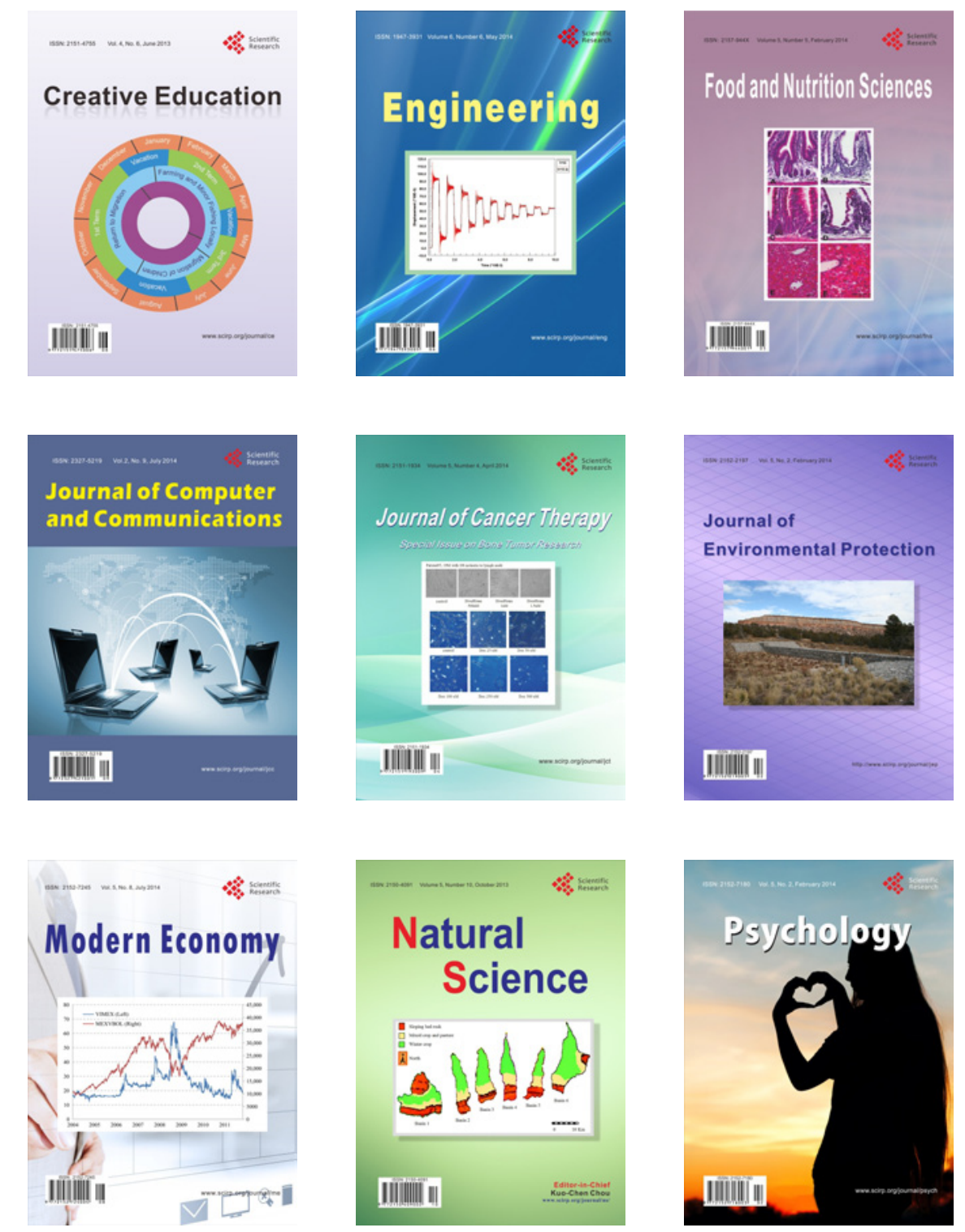